\title{
PHENOMENON OF AL-FARABI IN THE CONTEXT OF THE WORLD PHILOSOPHY
}

\author{
${ }^{1}$ A.Zh. Saduov, ${ }^{2}$ A.T. Makulbekov, ${ }^{3}$ A.M. Malikova
}

\section{ABSTRACT}

Al-Farabi laid the foundations of the philosophy of mutual understanding, following the principle of tolerance towards other cultures, religions and spiritual practices. He carried out a constructive dialogue between the philosophy of antiquity and the philosophy of the Middle Ages, Islam, Christianity and Judaism and organically entered into the modern discourse of the Kazakh philosophy of mutual understanding.

In his teaching on mutual understanding, Al-Farabi revealed the unlimited possibilities of an integral communicative dialogue between completely different spiritual and intellectual worlds. The principle of mutual understanding as a way of mastering the semantic philosophical space of the ancient heritage allowed him to reveal the dialogic essence of philosophy and understand it as a dialogue of free, equal spiritual and intellectual practices. Through the prism of Al-Farabi's philosophical heritage, the great meaning of the philosophy of mutual understanding is clarified.

Keywords: Philosophy, Culture, Phenomenon, Encyclopedist, Teacher, Scientist, Development, Science, Heritage, Civilization, Aesthetics, Ethics, Logic.
1,2 L.N. Gumilyov Eurasian

National University,

Nur-Sultan, Kazakhstan

${ }^{3}$ Kazakh National University

of Arts, Nur-Sultan,

Kazakhstan

Corresponding Author:

A.M.Malikova,

malikova.asel@mail.ru

Reference to this article:

Saduov A.Zh., Makulbekov A.T., Malikova A.M. Phenomenon

of al-Farabi in the Context of the World Philosophy//

Adam alemi. - 2021.

- No. 2 (88). - P. 42-51.

\section{Әлемдік философиялық ғылым контекстіндегі әл-Фараби феномені}

\begin{abstract}
Аннотация. Әл-Фараби басқа мәдениеттерге, діндер мен рухани тәжірибелерге қатысты толеранттылық қағидатын ұстана отырып, өзара түсіністік философиясының негізін қалады. Ол ежелгі заман философиясы мен орта ғасырлардағы ислам, христиан және иудаизм философиялары арасында сындарлы диалогты жүзеге асырып, қазақстандық өзара түсіністік философиясының заманауи дискурсына органикалық түрде кірді.

Өзара түсіністік туралы ілімінде әл-Фараби мүлдем басқа рухани және зияткерлік әлемдер арасындағы интегралды коммуникативті диалогтың шексіз мүмкіндіктерін ашты. Ежелгі мұраның мағыналық философиялық кеңістігін игеру тәсілі ретінде өзара түсіністік қағидасы оған философияның диалогтық мәнін ашып, оны еркін, тең рухани және интеллектуалды тәжірибелердің диалогы ретінде түсінуге мүмкіндік берді. Әл-Фарабидің философиялық мұрасының призмасы арқылы өзара түсіністік философиясының үлкен мәні айқындалады.
\end{abstract}

Түйін сөздер: философия, мәдениет, құбылыс, энциклопедист, мұғалім, ғалым, даму, ғылым, мұра, өркениет, эстетика, этика, логика. 


\title{
Феномен аль-Фараби в контексте мировой философской науки
}

\begin{abstract}
Аннотация: Аль-Фараби заложил основы философии взаимопонимания, следуя принципу толерантности по отношению к другим культурам, религиям и духовным практикам. Он осуществил конструктивный диалог философии античности и философии средневековья, ислама, христианства и иудаизма и органично вошел в современный дискурс казахстанской философии взаимопонимания.

В своем учении о взаимопонимании аль-Фараби раскрыл неограниченные возможности интегрального коммуникативного диалога между совершенно различными духовными и интеллектуальными мирами. Принцип взаимопонимания как способ освоения смыслового философского пространства античного наследия позволил ему раскрыть диалогическую сущность философии и понять ее как диалог свободных, равноправных духовноинтеллектуальных практик. Через призму философского наследия аль-Фараби проясняется великий смысл философии взаимопонимания.
\end{abstract}

Ключевые слова: философия, культура, феномен, энциклопедист, учитель, ученый, развитие, наука, наследие, цивилизация, эстетика, этика, логика.

\section{Introduction}

Abû-Nasr Muhammad ibn Muhammad ibn Uzlag ibn Tarhan al-Farabi at-Turk is the full surname of Al-Farabi, who was a person of encyclopedic learning, a prominent scientist, and a great teacher, second after Aristotle. Al-Farabi was born in the year of 870 in a district of the city of Otrar, one of the most significant centers of the Silk Way.

From the early years, he visited such cities as Bukhara, Samarkand, Merv, Baghdad, Harran, Rey, Cairo, Aleppo, and Sham. Scientific efforts of Al-Farabi pertain to the golden age of the medieval Arabic and Muslim culture, i.e. to the so-called Islamic Renaissance of the $10^{\text {th }}$ century of the Common Era.

Speaking of Al-Farabi's perception of the philosophy of Aristotle, the former links together the antique philosophy and the Islamic philosophy. Thanks to Al-Farabi's tractates only, many famous medieval thinkers could gain a correct understanding and due appreciation of the philosophical messages of Plato and Aristotle.

In this regard, Al-Farabi is associated with the antique tradition, and this is why he became the 'Second Teacher' after Aristotle and came to prominence. We have data evidencing that Al-Farabi was familiarized with the works of great Aristotle, Plato, and other Greek philosophers from his very childhood.

\section{Research Methods}

This article uses the method of hermeneutical, ontological, anthropological, axiological, conceptual analysis in determining the place of AlFarabi in the world space. To reveal the philosophical essence of a social character in society, the method of anthropological analysis is first of all used in revealing the anthropogenic essence of society. Scientific research methods such as historical-logical, comparative, content analysis, epistolary are used in the research.

\section{Main part}

According to French philosopher Etienne Gilson, one cannot understand tractates of medieval Islamic thinkers, such as Al-Kindi, Al-Farabi, Ibn Sina, without first studying the writings of Thomas Aquinas, Duns Scotus, and other European philosophers. Philosophical transactions of Al-Farabi directly influenced the evolutionary process of the medieval European Renaissance.

Al-Farabi was concerned with two principal points:

1) elimination of contradictions between the philosophy of Plato and philosophy of Aristotle along with their harmonization;

2) elimination of contradictions of opinions in the Islamic worldview and in the ancient Greek philosophy [1]. 
One of the critical judgments spoken at that time against the Greek philosophy was the controversy between Plato and Aristotle. If philosophy is meant to show the path to perceiving the only truth, how can the two largest philosophical systems oppose one another? If both systems lead to the truth, they should not have any contradictions; and if we accept the existence of contradictions and acknowledge that both systems are correct, it means that philosophy is not completely perfect and cannot discover a way to the truth. That was the overall message of the critics leveled against the philosophy of that time.

In response to such challenges, AlFarabi wrote "The Harmonization of the Two Opinions of the Two Sages: Plato the Divine and Aristotle" («Аль-джамам бейт рай альхакимен Ефлятун аль-лияхи уа Аристо»). In this text, Al-Farabi stressed that the only discrepancy between Plato's and Aristotle's views resides in the use of different linguistic styles and different ways of living, while philosophical opinions of both thinkers were the same. In the beginning of the book, Al-Farabi spoke of the subject of philosophy, gave the classification of sciences, and provided a brief summary of Plato's philosophy. In the closing part of the book he described the key characteristics of Aristotle's philosophy and pointed out the commonality and the harmony of the opinions of those two sages.

Al-Farabi wrote that a man knows and understands the meaning of happiness through the theory-based strength of mind. It happens when the man gets to know his first education and starts to use it. The theory-based strength attempts to find a path to happiness, while the practice-based strength of mind broods over specific actions needed to be taken to achieve such goal. Actions developed through available means and trains of thought are then attempted. Imagination and strengths of senses prepare and help the strength of mind; they cause the man to take actions that influence his way to happiness; and only after that the man reaches the total welfare [2].
In fact, our ancestor Al-Farabi used to be a spiritually mature person in his youth, being ready for the great wisdom and sagacious servicing, to which he dedicated all his conscious life. He was educated in the Academy of Islamic civilization and steppe inhabitants, the largest library in the world, as well as in Alexandria, known to be the center of the global science, and in the famous spiritual hub of Otrar before the invasion of Chenghis Khan.

Born in the family of a high-ranked military man, he decided to take a risk to reject a dedicated service and entered upon a challenging and fascinating path of professional philosophy and science. He had to travel a long journey far from the place of his birth towards the centers of education and science in the cities of Harran, Egypt, Aleppo, and Bagdad.

That is not to say that the scholar, who had spent all his childhood and youth in the Arabic world, never missed him homeland during those wanderings. It is reflected in the following verses: 'Forgive me, my Fatherland, for I left you. Forgive me, my Motherland, for I made my way to far away. Forgive me, my Conscience, for I have chosen the path of knowledge' (unofficial translation) [3].

It is also demonstrated by another poem of his: "My country, I left not to find glory and happiness, but to discover the torches of science. I have been worth the white milk you'd given to me for as much as I could; I am your eighty-year old child from Assam..." unofficial translation) [4]

The 'happiness' is the central concept in the social philosophy and ethics of the thinker. Happiness is the supreme perfection, the ultimate goodness, the goal of each man's living. In his tractate 'The Way to Happiness', Al-Farabi said: 'We see that in order to be happy we do not need to pursue any other goal, so the outcome is that the happiness should be for us, and not for anyone else. Happiness is one of the most attractive, outstanding, and mature blessings'.

According to Al-Farabi, happiness is multi-faceted, and, as all other notions, multilayered and not obvious. It can be 
explained by no definition and valued by no measure; and yet, Al-Farabi does not deny that a person or a group of persons may see the happiness in their own way. In the book 'The Way to Happiness', the philosopher wrote: "We have seen that we do not need anything to be happy". He said that we need to improve ourselves to get there. It is difficult to understand the meaning of human happiness without a broad description of the significance and value of a human life. The quest for happiness resides in finding the overall value of living along with the satisfaction of all personal wants and creative needs in self-fulfillment and their individual and social realization. According to Al-Farabi, 'happiness takes such a place among rewards that you will strive to have methods and things which can lead to happiness' [5].

For Al-Farabi, spiritual understanding of human deeds on the way to happiness is important because it is a socially significant action, both from the point of view of how a man acts when guided by his desires and from the point of view of him receiving praise or shame from the society. A natural action related to the stress of a human soul is not enough to achieve happiness. A desire to do something good and prominent by itself is of little value. To gain confidence that his actions are apprehensible, the man needs to see that the society acknowledges the virtue of such actions. Thus, the philosopher says: 'we need to determine which of our actions are right, what emotions we should feel, and what aspirations we should have to reach the good mind' [6].

Therefore, a man can reach happiness and self-perfection only through the system of social relations formed in the society and between individuals. It means that each person should compare his or her natural inclinations, behavior, and temperament against the requirements of the society and its system. Such system would have a defined and adopted system of measuring human actions. In other words, you cannot realize it in line with your own natural inclinations, character, passions, and suchlike only. Demands of the 'co-existence of humans' precondition the need in training individuals, forming certain traits not given by nature, getting education in the world of human culture, i.e. performing the duties, rather than simply following one's own desires. According to Al-Farabi, each person is naturally gifted with a trait, thanks to which 'human emotions, intellect, and actions are and will be pleasant' [6]. It means that everyone has an opportunity to choose either moral, or amoral actions.

Al-Farabi discusses the issue of the moral nature in his tractates. However, his major social and ethical tracts such as 'Civil Policy', 'Designation of Happiness Ways', and 'The Way to Happiness' allow identifying the principal direction of the philosopher's endeavors in understanding the nature of morale. Al-Farabi highlights that an important condition of happiness is a man's freedom of choice and his actions based on his own free will. Al-Farabi places a high emphasis on the man's freedom of choice, on the right or wrong. Free will is set by the rationality of the soul and constitutes a covenant for the formation and enhancement of the moral virtue, attributable only to a human being.

The first goal is reached by acquiring significant values and intellect. Al-Farabi sees the concept of happiness as the subject of ethics, the subject of civil or political philosophy that deals with human actions and behavior. His pattern of thinking combines the knowledge of urban residents, method of political power organization, and management of actions and behavior of the society members. A part of the civil science shows the difference between the real and the pretended happiness. It is followed by the list of actions, behaviors, morale, and shared will of cities and nations. Only the civil science analyzes the path to the ultimate goal of the mankind - reaching happiness, and happiness is reached through individual traits of humans as well as their good and virtuous deeds.

One of the papers written by Abû-Nasr Al-Farabi closer to the downhill of his life is often named in Kazakh as 'Treatise on the 
Views of the Residents of the Virtuous City' (Мабади ара ахл аль-мадина аль-фадила ва мудадатиха). Sometimes, the end of the phrase is interpreted as 'The City of the Good".

It is known that all texts by Abû-Nasr Al-Farabi were written in Arabic. Besides, it is beyond argument that he did have a Muslim mindset. Before our country gained its independence, Al-Farabi's works had been analyzed apart from the religion, but since Kazakhstan gained its sovereignty, it has become possible to study and analyze them in relation with religious concepts. Till the present day, people continue to translate, praise, and promote the legacy of the outstanding scholar in the Kazakh language.

The distinguished legacy of Al-Farabi has an immense significance for the contemporary society. In particular, matters related to a human being, his values, his goal and way of living, as well as necessity to live together in peace and reconciliation and reach mutual understanding, become important for the modern community. Abû-Nasr Al-Farabi's 'Treatise on the Views of the Residents of the Virtuous City' is a philosophical tractate dedicated to the social and political position of the mankind, settlement of our fundamental problems, and regulation of relations within the society.

Researchers claim that Abû-Nasr AlFarabi started that text in Bagdad and finished in Damask in the $331^{\text {st }}$ year of Hegira. The underlying reason for creating this book resides in the author's disappointment in the society he lived in, because that was a society pulled apart by dissention and internal religious discords.

The tractate 'Treatise on the Views of the Residents of the Virtuous City' consists of two main parts. The first section is dedicated to the God and His attributes; creation of the entire universe, its origin and creatures; human kind, human soul, and the messenger between the humanity and the God; and also to the prophecy and its characteristics.

From the philosophical point of view, this part considers the physical world: first of all, the matter, four elements and materials, inanimate objects, and then the nature of plants, animals, and humans. The second section gives a comprehensive analysis of the 'Virtuous City', its peculiarities, characteristics of its residents, requirements applied to the administrator that manages the City, as well as differences from the ignorant amoral citizens who stand against the etalon city.

In respect of the inhabitants of the Great Steppe, both Al-Farabi and Abai state that they have common spirituality, centerpiece, harmony, and interrelation of certain ideas. 'Ethical thinking of Al-Farabi begins in reaching beauty and happiness' [7]. Specifically, ethical and social concept of the upbringing of Abai and all Kazakhs originates from the assessment of a human being, his or her happiness, and essence of the human existence. Abai's legacy is 'reflected by his urge to the beautiful, which underlies all creative efforts of the great poet', academic A.Kh. Margulan said, hitting the very mark.

Both Al-Farabi and Abai are, above all, teachers, and their philosophical studies and ideas are aimed to the maximum improvement and development of a human individual. While Al-Farabi wanted to find methods to bring people to the real happiness, Abai suggested a concept of the perfect man (responsibility). Ideas of Al-Farabi and Abai on the creation of Earth, as well as their abstract cosmological ideas, are similar. Al-Farabi said: 'Everyone has his own place in this world' [7].

Abai revoices it by saying: 'You are a little brick in the wall of the world. Find your place in it' [9]. Such relevancy of ideas can be continued. A.Mashanov, the researcher of the question of 'Al-Farabi and Abai', considers that Muslim Clerk Shigabutdin Marjani was more focused on Al-Farabi's tractates on philosophy, music, and natural sciences, which connected the two thinkers through the historical succession.

Abai's spiritual world is a special mystical place, where a human being is a major subject of study. Aesthetical and ethical sides of a man, his goal, dreams, reason to live, emotions and intuition, 
and also character and peculiarities of the national thinking had a profound effect on the great thinker. They form the basis for the philosophy of a person and personality.

Abai said: 'The Nature dies, but a person does not die, nor returns and nor plays...'.

The problem of a human being, his attitude to the world and essence of a human life constitutes the centerpiece of philosophy, being its principal issue. For instance, the present-day systemic crisis, which we all face, is a crisis of the radical attitude of the mankind to the world and a complicated human problem, which Abai, as an oriental sage, considers in a largescale format within the social, spiritual, value-based, ethical, or aesthetical aspects. This is the core of the problem, and, definitely, all of them are closely interlinked.

According to Al-Farabi, a person reaches perfection through science, philosophy, and education. A special attention is paid to the matters of behavior (moral), morale and intellect, and intellectual upbringing, for they are key instruments that lead the man to the true happiness and ideals. 'When we demonstrate good behavior and intellect, we are happy because of them. When we have those two, both we and our actions become dominating and perfect, thus making us truly respectful, kind, and virtuous', - the Great Teacher said.

In his thirty eighth Word, Abai resumes his thoughts on the integral and virtuous man as follows: '...then saints, then rulers, and finally true Muslims' [8].

The principal credo of Al-Farabi's philosophy states that people should live in mutual help, friendship, and peace on their way to happiness. 'As for people', he writes, 'they are linked by morale. [7]. That said, since they all belong to a human family, they should maintain mutual peace and harmony.'

Further to this tradition, in his thirty fourth Word, Abai said: 'All people are friends and guests. Hence, when you live in this world, you are interconnected, you grow up, you are well-fed, you are hungry, you are sad, you are fat, you are in a good physical shape, you are born, you are destined to die, you will go to the grave, you will decay. I hope you enjoy benefits of the both worlds as they are the same. You may or may not have 5 days of living. You are guests of each other and guests of the world, so do you deserve to argue on someone's knowledge, quarrel, or boast?' [8]

The notion of 'labor' is given a special place in the ethical concept of Abai. 'Honest labor and worthy money making are appreciated by people' - this is idea of work that should be propagated. We can say that practically all texts of the poet would touch upon the fact that honest and diligent labor plays a key role in a human life. He believed that labor is a principal instrument for the formation of a person, both spiritually and intellectually. The poet also concludes that the soul of a working man is full of kindness, while lazy ones, who do not know what they are worth of, often happen to be impish.

This is the reason why he wrote: 'Laziness is the enemy of arts around the world. Pointlessness, melancholy, shamelessness, and poverty - they all come from that' [8]. In short, the poet considered labor to be the source of the supreme goodness, the highest measure of the human character, the main indicator of servicing to people, the manifestation of the nation's dreams and interests, and the protection of its honor. Paying a lot of attention to the role of the environment and upbringing in the process of each man's establishment as a personality, the great poet stressed that everyone should work at one's own selfeducation on a systematic basis.

Abai has rightly pointed that the soul of a man is constantly changing and developing. According to the major principle of compassion and ethics, called 'Adam bol' ('Be a man'), there is a common mistake of a wrong interpretation of the word 'citizen' in the context of the maturity process. Today, the principal task is to see and develop the human-related side of a person, to assess an intelligent and educated person, to remain a worthy man for the entire life, to grow old in serving one's nation, and to love and respect the whole humankind [8]. 
As many other outstanding sages of the East, Abai had solid confidence that improvement and modernization of the society could be achieved through improving the conscience of people, and he believed that if he sent his nation to that path, he would be most helpful. This is fully supported by his ideological and cultural aspirations. Abai knew that the entire world is always changing and developing. The idea of dialectics is reflected in the poet's verse 'we grew old, we thought of sadness, we were deep asleep' (unofficial translation), in his twentieth, thirty seventh, and thirty eighth Words, in his poem 'The God is true, and His word is true', and in many other of his works.

Everything described in the texts of Abai, except for the Creator, is changing and developing within this life, and society considers life as a place for the constant renewal of generations.

This means convergence of Al-Farabi and Abai, their harmonization, and revival of the spiritual and cultural world of our nation that has a thousand-year history. Therefore, it is the great goal of the nation. It is true that a lot has been done to know more about those two titans of thought individually. Yet, we still cannot trace that amazingly thin spiritual thread that connects them, 'though we vividly feel its existence, we are far from actually "seeing" $i t^{\prime}$, Akzhan Mashani says [9].

When we compare Abai's texts with tracts of earlier oriental scholars, we discover much in common and much similar. Especially, it is true for scientific, religious, educational, and creative aspects. Abai and Al-Farabi serve as an example, giving us similar, close, and complementary ideas and thoughts in various spheres. It is important to mention their interrelation in terms of pedagogical and educational contents, and in terms of their roots.

According to the ancient tradition of the Islamic Caliphate, the main condition was to require the head of the country, the ruler, to be 'eight-sided' - a person of knowledge and character. Al-Farabi is at the forefront of those who implement this idea in the demand-based pedagogy. He believed that the core objective resides in determining what education should be availed to talented children to grow them into mature leaders and rulers. Al-Farabi names twelve such traits, both naturally inherited and obtained in youth.

It lookslike AbaiKunanbayevich masterly continued Al-Farabi's philosophical views on the intellect that had remained relevant after nearly nine centuries and could be applied in the new historical environment of the Kazakh commune. In his nineteenth Word, Abai said: 'the one who hears the words of the deaf becomes deaf himself. If you take into consideration good things you hear and know with your senses, and avoid evil ones, then it will work, and you may be named a worthy man' [8].

Besides, Al-Farabi's philosophical statement on the role of intellect for discovering science and knowledge was brightly expressed by Abai in the latter's nineteenth Word. Abai said: 'From the very beginning, a child does not seek knowledge on his own. At first, it is needed to be tight to violence or deceit, until you get used to that and then find what you were looking for. Only when a child is taken with science and knowledge, he may be named a human' [8]. It is no coincidence that notions and terms used by Al-Farabi in his above-mentioned work on the 'energy of soul' are replicated in the same manner in Abai's explanation of improprieties (Words: 7,17,27,38,43).

Al-Farabi states: 'The strength of mind is the power that helps any man to think, consider, understand science and art, and distinguish good from evil'. In his philosophical tract 'Treatise on the Views of the Residents of the Virtuous City', Al-Farabi explained such concepts of 'Strength', 'Mind', and 'Heart': 'The heart is the major organ, not known to any other body part. It is followed by the brain. It is also a key organ, but not the first one' [10]. It looks like philosophical thoughts of Al-Farabi on the 'Strength', 'Mind', and 'Heart' found their logical continuation in the seventeenth Word by Abai.

According to Abai, that triad, Strength, Mind, and Heart, consider themselves to be strong, they keep arguing and finally apply 
to the Science. The Science explained that all three of them had been right, and all three of them were necessary.

Literature-based communication contributes to the rapprochement of the cultures of various nations and development of spiritual relations.

N.I. Konrad, a famous Eastern scholar, said: 'One of the factor of growth and development of the national literature resides in the interaction with literatures of other nations. It is a known fact that any literature consists of two components. One of them includes authentic texts created in the very same country, while the second embraces texts imported from other countries. Literature-based communication, standing on the basis of such worlds, has a very special role' [11].

Al-Farabi is the brightest star among noble offsprings of the Kazakh steppe, and his name is known to the entire world, while his scientific and cultural legacy has been honored for centuries and passed from one generation to another. For more than a thousand years, up to now, the works of our brilliant ancestor have served as a source of inspiration for numerous scholars throughout the globe. The legacy of his great mind covers various fields of science and has an immense value. We can say that his theory-based views on philosophy, sociology, logics, aesthetics, ethics, and other spheres of both natural and humanitarian sciences have influenced social and philosophical thinking of many nations of the world.

The bibliography 'List of Al-Farabi's Texts' by Turkish scholar Ahmad Atash (Istanbul, 1950) has 160 Al-Farabi's books [12]. That paper is important for it fixes in which country, where, in what form, and under what number Al-Farabi's texts were registered. Soviet scholar Bertels Ye.E., speaking on the Arabic literature history, states that in the books of famous medieval Arabic poets and historians AlFarabi is mentioned as a great maker of rhymes who wrote many poems.

Al-Farabi's legacy has become a basis of scientific efforts of many scholars and researchers, while his character inspired many writers. One of our national authors, Anuar Alimzhanov, having profound historical knowledge, wrote a novel on genius philosopher Al-Farabi, named 'Return of the Teacher'. It shows various aspects of the life of the wise scholar.

Speaking of Al-Farabi's tracts on the literature critics, we can see that he was a fabulous writer and poet. N.Kelimbetov, a well-known literature expert, wrote: 'AbûNasr Al-Farabi was a scholar who also dealt with the theory of literature. Based on the preserved lists of his transactions, we know he authored a number of important papers on the theory of literature' [13].

The scholar, who had been recognized as the second after Aristotle teacher, published his major theory-related views and analyses in his tracts: 'Rhetoric', 'Epistle on the Canons of Poetry', 'On the Art of Poetry', 'Treatise on the Classification of Sciences', 'Speech on Poetry and Harmony', and others. His theoretical ideas and artistic and aesthetic worldviews reflected in those texts have not lost their essence and meaning. In studying that branch of the science, he followed in the steps of his predecessors, having absorbed and developed their traditions.

Dealing with such three disciplines as logic, politics, and metaphysics, Al-Farabi was the first one in history who obtained deep knowledge in those three spheres. He found new sources in the area of science, especially in the discussion of logical perception. 'Thanks to Farabi, logic is the science about laws and rules of thinking. Due to that science, a person can develop one's mind, make one's thoughts clear and systemically structured, and avoid logical mistakes while thinking, considering, or discussing' [14]

The thinker divides logic into eight points as follows: 1. Categories related to the use of simple terms and to the sequence that overrules the concept; 2 . Simple opinions and judgments consisting of two terms and more; 3. Regularity of syllogisms applied to five various arguments - dialectic, sophistic, rhetoric, and poetic; 4. The sequence of proving scientific knowledge; 5 . Dialectic questions 
and answers; 6. Reading sophistic examples; 7. Rhetoric and its impact on the listener; and 8 . Theory of poetry related to various poetic ideas and harmonies.

In his tract 'Treatise on the Views of the Residents of the Virtuous City', Al-Farabi suggested a code of ideal communities, administered by a well-educated mayor, based on peace and serenity. He said, 'The ability to discover the inner world of the man and influence his emotions requires knowledge'. Considering a human being as the supreme stage of the sublunar sphere, the sage develops the teaching on the properties and strengths, or abilities, of a human soul. Being a wonderful creature of the nature, a human being had various abilities and powers: for instance, a causing power, a power of sense, a power of imagination, a power of rational thinking, an impelling power, a motivating power, Al-Farabi explained.

\section{Conclusion}

Abû-Nasr Al-Farabi spent his entire life in his dedication to humans. Key issues that engaged all Arabic-speaking philosophers included knowledge, perception, and search of the Truth in the world. Those issues were associated with the human choice and freedom, which, in turn, were linked to the matter of the cause-andeffect relation depending on the man's attitude to philosophy and religion, as well as his choice of knowledge or faith. The history of the philosophical thought of that epoch is inseparable from the history of Islam; religious perception and philosophy constituted a complicated, contradictory, but magnificent image of the so-called 'Golden Age' [15].

The history of the medieval science and philosophy cannot boast of having many thinkers who would have left a legacy of theoretical science knowledge equal to Abû-Nasr Al-Farabi. He is a well-deserved sage from East to West. Most scientists read tractates of the settled thinker and commented them. His philosophy gave an impetus to the effective evolution of scientific thought. Books of Abû-Nasr AlFarabi were taught in European universities. Renaissance was recognized as the leader in the field of science, and Al-Farabi as a special man and a fount of wisdom. He had a unique energy and enthusiasm of a self-bestowed scholar and made his contribution to all spheres of culture.

This is the exact reason why both West and East have been discussing his endless legacy for so long. His system of philosophical ideas is the paramount of the medieval theoretical thinking. He strived not only to find the truth, but to use it to find happiness for the whole mankind, and the search of human happiness in a wellmanaged society was a fair decision. He unmasked injustice, lies, double-dealing, and jealousy. He wanted to bring rightness and ruling of mind as the cornerstone of the human community [16].

Proclaiming the idea of humanity in the face of constant antagonism and conflicts was a heroic act. He propagated that the path of the humankind to the good morality would save the Universe. He awoke the personality and rationality of a human nature. His passion to beauty and emotional music served as the key. He led people to their physical, intellectual, and spiritual evolution. His life was an example of patience and conversion. He demonstrated the harmony of his body and soul, his healthy lifestyle, and secrets of healing.

Many outstanding masterpieces were created in the emerging social and philosophical conscience influenced by encyclopedic scholar Al-Farabi and his contribution into the development of the world philosophy. Up to now, the entire mankind scrupulously reads his texts and highly appreciates this amazing legacy of the past. New generation admire the phenomenon of Al-Farabi. Scholars throughout the globe should work together to fully discover the legacy of the great thinker. It will be the most providential and sincere attention of the kind-hearted human race to the children of the steppe civilization. 


\section{References}

1. Kobesov A. Al-Farabi. - Almaty: Kazakhstan, 1971. - 18 p.

2. Philosophical heritage of the Kazakh people. - Astana, 2007. - Volume XII. - 480 p.

3. Beisenov K. Sh. History of philosophy. - Shymkent, 1992. - 87 p.

4. Begalieva K. The problem of man and the world in Kazakh philosophy. - Almaty, 2000.

5. Zharykbayev K., Aldamuratov A., Gabitov T. Fundamentals of ethics. Almaty: Murattas, 1997. - 114 p.

6. Nysanbayev A. Man and open society. - Almaty: Kaz. encikl., 1998. - 328 p.

7. Al-Farabi. Philosophical treatises. - A., 1972.

\section{INFORMATION ABOUT AUTHORS}

Asylhan Saduov

Aidos Makulbekov

Assel Malikova

Асылхан Жумабаевич Садуов

Айдос Төлебекұлы Мақұлбеков

Асель Мәлікқызы Мәлікова

Асылхан Жумабаевич Садуов

Айдос Толебекулы Макулбеков

Асель Маликкызы Маликова
8. Abay. Words of edification. - A., 1993.

9. Mashanov A. Al-Farabi and Abay. Almaty, 1994

10. Legacy. Al-Farabi and world culture. - Almaty, 2001. - 22 p.

11. Konrad N. I. West and East. Moscow: Nauka, 1972. - 496 p.

12. Kasabek A., Kasabek S. The search for truth. Almaty, 1998.

13. Ezhelgi dauir adebieti. Almaty "Ana tili" 1991. -280 p.

14. Al-Farabi and the development of Eastern philosophy. Astana: Elorda, 2005 - - 318 p.

15. Philosophical heritage of the Kazakh people. Astana, 2005. Vol. 2, p. 479, vol. 4, p. 533 , p. 7 , p. 543 , p. 16, p. 437.

16. Amrekulov N. Turkic Revival. Almaty, 2006. $-534 \mathrm{p}$.

PhD student, L.N. Gumilyov Eurasian National University, Nur-Sultan, Kazakhstan

PhD student, L.N. Gumilyov Eurasian National University, Nur-Sultan, Kazakhstan

PhD, Senior Lecturer, Kazakh National University of Arts, NurSultan, Kazakhstan

докторант, Л.Н.Гумилев атындағы Еуразия ұлттық университеті, Нұр-Сұлтан, Қазақстан

докторант, Л.Н.Гумилев атындағы Еуразия ұлттық университеті, Нұр-Сұлтан, Қазақстан

PhD, аға оқытушы, Қазақ ұлттық өнер университеті, НұрСұлтан, Қазақстан

докторант, Евразийский национальный университет имени Л.Н. Гумилева, Нур-Султан, Казахстан

докторант, Евразийский национальный университет имени Л.Н. Гумилева, Нур-Султан, Казахстан

$\mathrm{PhD}$, старший преподаватель, Казахский национальный университет искусств, Нур-Султан, Казахстан 